\author{
Marta WÓJCIK ${ }^{1}$ \\ Beata PAWLOWSKA ${ }^{2}$ \\ Feliks STACHOWICZ ${ }^{3}$
}

\title{
Recycling of automotive catalytic converters with ap- plication of magneto-hydrodynamic pump
}

\begin{abstract}
The automotive catalytic converter is a part of exhaust system in vehicles, which reduces the amount of harmful substances in exhaust fumes. The need of using automotive catalytic converters results from rigorous standards for exhaust fumes emissions, called EURO standards. In Poland, there is not any installation designed in order to recycle worn out automotive catalytic converters. Catalytic converters are purchased by individual entrepreneurs and exported abroad. This article presents a solution of recycling of catalytic converters which can recover precious metals contained in catalytic converters. This article also characterizes automotive catalytic converters and reviews the standards of exhaust fumes emission.
\end{abstract}

Keywords: automotive catalytic converters, EURO standards, magnetohydrodynamic pump, recycling

\section{Introduction}

The automotive industry and transport are the main sources of waste generated both during exploitation and utilization of vehicles withdrawn from the use. An increase in the number of vehicles to be scrapped might be observed every year. According to the data provided by the Central Registry of Vehicles and Drivers (CRVD), in Poland there were about 188,243 unregistered vehicles in 2007 [11]. Given the number of deregistered cars and assuming that the average weight of a car equals approximately $950 \mathrm{~kg}$, we can achieve an annual mass of scrap vehicles at 235,000 tones [12]. Most elements of the car have the value of raw materials. About $85 \%$ of the weight of exploited vehicles are materials that can be recycled in order to obtain raw materials for the production of new automotive parts. Steel, iron and large number of other metals used in cars are ideally suited for material recycling. Not only is the recycle rate for metals over 95

\footnotetext{
${ }^{1}$ Autor do korespondencji/corresponding author: Marta Wójcik, Politechnika Rzeszowska, 8 Powstańców Warszawy Av., 35-959 Rzeszów, tel.: (17) 865 1507, e-mail: martawojcik@onet.eu

${ }^{2}$ Beata Pawłowska, Politechnika Rzeszowska, e-mail: bpaw@prz.edu.pl

${ }^{3}$ Feliks Stachowicz, Politechnika Rzeszowska, e-mail: stafel@ prz.edu.pl
} 
$\%$, but also most metals can be reused several times without deterioration of quality. Formerly the conventional reprocessing of automobile scrap has essentially consisted of whole car compressed (excluding only a few parts) and metallurgical recycling such the scrap by melting it in a blast furnace or steel works. With the incineration of the plastic, rubber and coated parts, which also remain in compressed, scrap, poisonous and environmentally damaging gaseous compounds can develop. Appropriate filters must be used in attempt to prevent their emission. Therefore, it must be first known, which compounds can occur, in order to develop suitable retention system $[9,15]$. In the modern recycling procedure scrap cars are broken into pieces and after reclaiming the engine, battery, tire parts, etc. it is taken to shredder firms and crushed. The ferrous metals, aluminium, etc. are then removed from the shredder pile, the remaining is called shredder dust that includes various metal pieces, plastics, glass, ceramics and so on. A block diagram (fig. 1) shows flow chart for utilized automobile scrap that the aim is to reuse metal parts and recycle as well as recover metals.

In the current post-use processing for scrap vehicles (end of life vehicles ELV) is embodied by two industries; disassembling and shredding. The degree of car disassembling prior to shredding is highly dependent on profitability of removing valuable parts and other materials $[5,14]$. Disassembling of the end of life vehicles is very important from both the ecological, technological and economical point of view. Disassembled end of life of vehicles metal parts could be divided into several groups (fig. 1). According to different procedures complete or only partial disassembling could be performed [10]. A large number of disassembled metal parts, sometimes after renovation, could be sold as spare parts used to repair another car.

Recycling of worn out automotive catalytic converters is preferred from the economical point of view. It is estimated that processing of 2 tons of automotive catalytic converters might reduce ore production of about 150 tones. What is more, used catalytic converter is a valuable source of platinum and other platinum group metals (PGM). Generally, used automotive catalytic converters are most often processed by pyrometallurgical (melting method and the method ROSETM) and hydrometallurgical methods (by chlorination, extraction cyanide or aqua regia). Technologies involve many steps, allowing the recovery of approximately $95 \%$ platinum and palladium and $70 \%$ rhodium. They are often used as a combination of both methods, which allow a higher percentage of recovery of precious metals [4].

In Poland there are technological possibilities for processing most of the automotive waste but there is not any installation which would be able to recycle worn out automotive catalytic converters. Many private entrepreneurs are engaged in buying worn out automotive catalytic converters and in turn, automotive catalytic converters are exported abroad. This phenomenon is very common in Poland due to the high prices of used automotive catalytic converters with costs amounting to even a few thousand PLN. With reference to proximity prin- 
ciple, the new method of utilization of automotive catalytic converters has been proposed. Using magneto-hydrodynamic pump and liquid metal can recover precious metals contained in catalytic converters. Detailed information concerning this method is included in further section of the article.

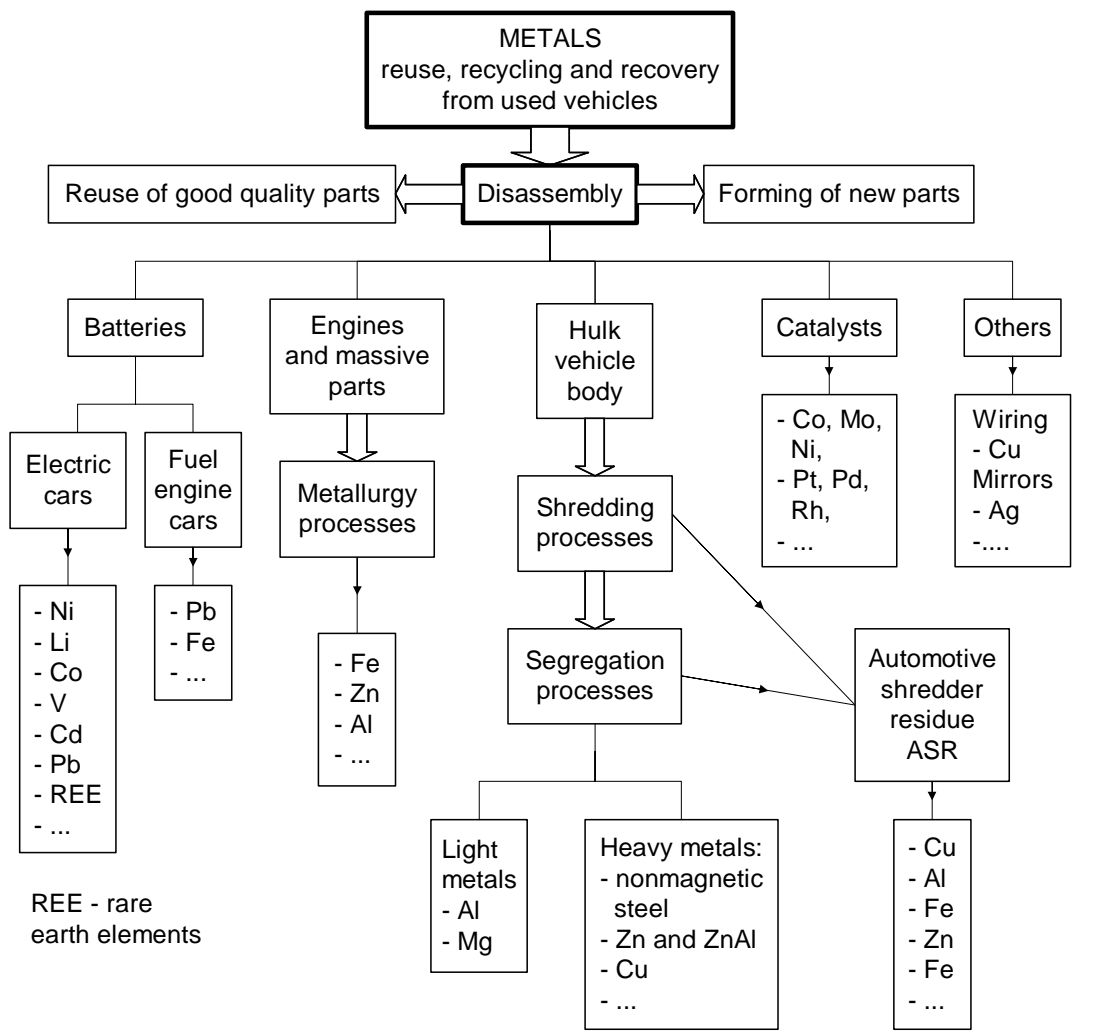

Fig. 1. Flow chart for utilized scrap automobiles processing oriented on recovering of different metals

\section{The characteristics of automotive catalytic converters}

An automotive catalytic converter is a part of the exhaust system which can reduce the amount of harmful substances contained in exhaust gases. Formerly, owing to the relatively stringent standards of emission, catalytic converters were not used. At present, due to strict standards, catalytic converters have to be installed in other devices powered by internal combustion engines, trucks, buses, locomotives and even in forklifts. The automotive catalytic converter consists of a core made of metal or ceramic monolithic with the honeycomb structure, the intermediate layer, the active layer, the sealant and an insulating layer in the form of a mat and a heat-resistant casing made of corrosion-resistant steel. The catalytic converter contains monolithic carriers on which are placed coatings 
including catalytically active elements such as: platinum (Pt), palladium (Pd) and rhodium $(\mathrm{Rh})$, less frequently ruthenium $(\mathrm{Ru})$. The monolith catalyst consists of a large number of channels arranged in the direction of exhaust flow. The channels are separated by thin walls, which in the cross-section resemble a honeycomb structure. Based on the applied carrier material, we can distinguish metal and ceramic catalytic converters.

Ceramic monoliths usually have channels in the shape of a square. We can also distinguish rectangular, triangular and hexagonal ceramic monoliths. Cordierite ceramics is commonly used for the production of ceramic automotive catalytic converters, for instance $2 \mathrm{MgO}-\mathrm{Al}_{2} \mathrm{O}_{3}$ has the following weigh composition: $50 \% \mathrm{SiO}_{2}, 36 \% \mathrm{Al}_{2} \mathrm{O}_{3}, 14 \% \mathrm{MgO}$ and contains a small amount of ingredients in the following form: $\mathrm{Na}_{2} \mathrm{O}, \mathrm{Fe}_{2} \mathrm{O}_{3}, \mathrm{CaO}$ which act as fluxes and stabilizers [2].

Metal monoliths are made of thin steel film resistant to corrosion. Metal catalytic converters are formed by rolling two plates with different structures. Then they undergo the processes of soldering or welding. Metal carriers are usually made of stainless $\mathrm{FeCrAl}$. The average composition of the automotive catalytic converter is presented in the table (Table 1). The metal catalytic converter is preferred as it heats up rapidly, and therefore reaches the operating temperature faster, and as a result purifies exhaust fumes faster. In addition, the metal catalytic converter is less sensitive to fluctuations of temperature and the maximum temperature causing its destruction is higher than of the ceramic catalytic converters $\left(1300^{\circ} \mathrm{C}\right.$ for a metal catalytic converter and $800^{\circ} \mathrm{C}$ for ceramic catalytic converters). Metal catalytic converters have also greater resistance to mechanical damage and lower resistance to flow. Among the advantages of the ceramic catalytic converters are: low thermal expansion and good surface development that allows for a beneficial distribution of the catalytically active phase. The main disadvantage of the catalysts is the need for a mat ceramic fiber, protecting the catalyst from breaking at the time of shock and reducing the differences in thermal expansion in relation to the metal housing [7].

Table 1 . The average composition of the automotive catalytic converter

\begin{tabular}{|c|c|}
\hline \multicolumn{2}{|c|}{ The average composition of the automotive catalytic converter, $\mathrm{g} / \mathrm{dm}^{3}$} \\
\hline $\mathrm{Al}_{2} \mathrm{O}_{3}$ & $100-200$ \\
\hline $\mathrm{CeO}_{2}$ & $40-80$ \\
\hline $\mathrm{Pt}$ & $1-2$ \\
\hline $\mathrm{Rh}$ & $0.1-0.4$ \\
\hline
\end{tabular}

The principle of the catalytic converter operation is to transform toxic compounds in substances less harmful to the environment, for example: nitrogen and water which undergo a series of transformations. Today catalytic converters serve three basic functions (hence the name tri-functional catalysts): oxidation of carbon monoxide (to carbon dioxide, which is not harmful to humans, neverthe- 
less contributes to the greenhouse effect), the oxidation of hydrocarbons (through forming water and carbon dioxide) and the reduction of nitrogen oxides. The efficiency of these changes is expressed by a conversion modulus:

$$
W K=\frac{Z S T_{P K}-Z S T_{Z K}}{Z S T_{P K}} * 100 \%
$$

where: WK - conversion ratio for a compound,

$\mathrm{ZST}_{\mathrm{PK}}$ - the content of toxic component in the exhaust gas ahead of the catalytic converter,

$\mathrm{ZST}_{\mathrm{ZK}}$ - the content of toxic component in the exhaust gas after the catalytic converter.

In practice, the efficiency of the catalytic converters can reach up to $90 \%$. In order to achieve high efficiency, cooperation between the catalytic converter and lambda sensor and an appropriate composition of the fuel-air mixture are required.

\section{Standards concerning the exhaust fumes emission}

In order to limit the impact of car exhaust fumes on the environment, the European Union implemented the directives defining the so-called emissions standards. European emission standards (EURO standards) determine permissible emissions for newly manufactured vehicles. The standards regulate emissions of nitrogen oxides $\left(\mathrm{NO}_{\mathrm{x}}\right)$, hydrocarbons $(\mathrm{HC})$, carbon monoxide $(\mathrm{CO})$ and solid particles emission for all vehicles (excluding ships and aircraft). The fact that the vehicle complies with the requirements of the Euro standard is determined by running the engine in a special test. Failure to comply with the standards of emission prevents the car from being sold in the European Union. It should be noted that new EURO standards do not apply to cars already driven on the roads $[1,7]$. Standards of emission are determined in the European Directives which gradually increase their stringency - currently, there are six EURO standards (tables 2 and 3):

- EURO I - the first standard concerning the exhaust fumes emission, obligatory from 1 July 1992 for cars and lightweight trucks, according to Directive 91/441/EC,

- EURO II - obligatory from 1 October 1996 (Directive 94/12/EC \& 96/69/EC for cars), requesting minor changes in relation to the EURO I,

- EURO III - introduced in 1 October 2001 (Directive 98/69/EC) for all vehicles,

- EURO IV - obligatory from 1 October 2006 (Directive 98/69/EC \& 2002/80/EC) for all vehicles, 
- EURO V - introduced in 2009 (Directive 2007/715/EC) for lightweight cars,

- EURO VI - obligatory from 2014 (Directive 2007/715/EC for heavy cars), according to the level of pollutants emitted by heavy vehicles.

Table 2. The value of emissions of gasoline-powered vehicles

\begin{tabular}{|c|c|c|c|c|c|c|}
\hline \multicolumn{7}{|c|}{ The value of emissions of gasoline-powered vehicles } \\
\hline $\begin{array}{c}\text { EURO } \\
\text { standard }\end{array}$ & $\begin{array}{c}\text { Effective } \\
\text { from }\end{array}$ & $\begin{array}{c}\mathrm{CO} \\
\mathrm{g} / \mathrm{km}\end{array}$ & $\begin{array}{c}\mathrm{HC} \\
\mathrm{g} / \mathrm{km}\end{array}$ & $\begin{array}{c}\mathrm{NO}_{\mathrm{x}} \\
\mathrm{g} / \mathrm{km}\end{array}$ & $\begin{array}{c}\mathrm{HC}+ \\
\mathrm{NO}_{\mathrm{x}} \\
\mathrm{g} / \mathrm{km}\end{array}$ & $\begin{array}{c}\mathrm{PM} \\
\mathrm{g} / \mathrm{km}\end{array}$ \\
\hline EURO I & $12 / 1992$ & 2.72 & - & - & 0.97 & - \\
\hline EURO II & $01 / 1997$ & 2.20 & - & - & 0.5 & - \\
\hline EURO III & $01 / 2000$ & 2.30 & 0.20 & 0.15 & - & - \\
\hline EURO IV & $01 / 2005$ & 1.00 & 0.10 & 0.08 & - & - \\
\hline EURO V & $09 / 2009$ & 1.00 & 0.10 & 0.06 & - & 0.005 \\
\hline EURO VI & $08 / 2014$ & 1.00 & 0.10 & 0.06 & - & 0.005 \\
\hline
\end{tabular}

Table 3. The value of emissions of diesel vehicles

\begin{tabular}{|c|c|c|c|c|c|c|}
\hline \multicolumn{7}{|c|}{ The value of emissions of gasoline-powered vehicles } \\
\hline $\begin{array}{c}\text { EURO } \\
\text { standard }\end{array}$ & $\begin{array}{c}\text { Effective } \\
\text { from }\end{array}$ & $\begin{array}{c}\mathrm{CO} \\
\mathrm{g} / \mathrm{km}\end{array}$ & $\begin{array}{c}\mathrm{HC} \\
\mathrm{g} / \mathrm{km}\end{array}$ & $\begin{array}{c}\mathrm{NO}_{\mathrm{x}} \\
\mathrm{g} / \mathrm{km}\end{array}$ & $\begin{array}{c}\mathrm{HC}+\mathrm{NO}_{\mathrm{x}} \\
\mathrm{g} / \mathrm{km}\end{array}$ & $\begin{array}{c}\mathrm{PM} \\
\mathrm{g} / \mathrm{km}\end{array}$ \\
\hline EURO I & $12 / 1992$ & 3.16 & - & - & 1.13 & 0.14 \\
\hline EURO II & $01 / 1997$ & 1.00 & 0.15 & 0.55 & 0.70 & 0.08 \\
\hline EURO III & $01 / 2000$ & 0.65 & 0.06 & 0.50 & 0.56 & 0.05 \\
\hline EURO IV & $01 / 2005$ & 0.50 & 0.05 & 0.25 & 0.30 & - \\
\hline EURO V & $09 / 2009$ & 0.50 & 0.05 & 0.18 & 0.23 & 0.005 \\
\hline EURO VI & $08 / 2014$ & 0.50 & 0.09 & 0.08 & 0.17 & 0.005 \\
\hline
\end{tabular}

\section{Recycling of used automotive catalytic converters with magneto-hydrodynamic pump}

Exploited automotive catalytic converters can be recycled with contemporaneous recovery of precious metals by magneto-hydrodynamic (MHD) pump. Magneto hydrodynamics is a branch of hydraulics dealing with the movement of electrically conductive fluid in a magnetic field. Based on research carried at the Department of Materials Science and Engineering Technical University of Silesia, the magneto-hydrodynamic pump might be used in the recovery of platinum from worn out catalytic converters. MHD pump consists of a driver made of the magnetic cores on which the multi-phase windings were wound and the channel of the liquid metal located between the cores (fig. 2). The walls of the channel, depending on the temperature of the transported metal, would be made of steel, graphite or ceramic materials $[2,7]$. In this paper a flow sheet has been proposed. Aforementioned flow sheet can recycle automotive catalytic converters with a device based on MHD pump (fig. 3). 


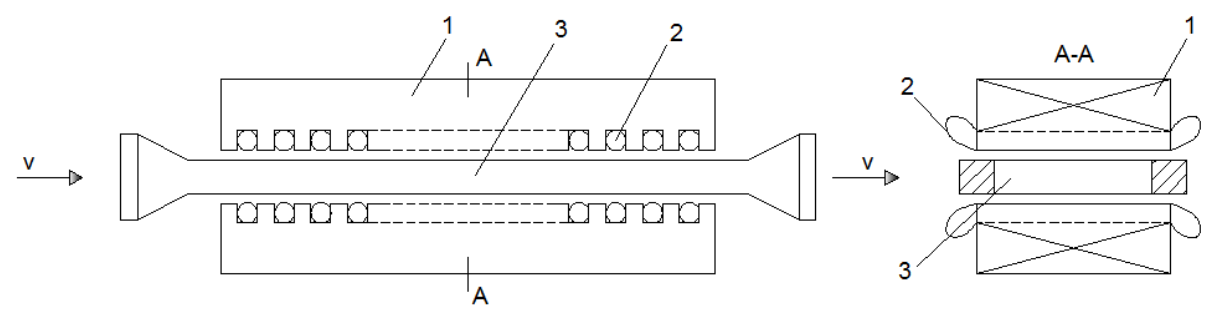

Fig. 2. The scheme of MHD pump: (1) driver made of the magnetic cores, (2) the multi-phase windings, (3) the channel with liquid metal

At the beginning of the process, it is necessary to cut monoliths from worn out catalytic converters with a layer of precious metals. The remaining waste from catalytic converters (mainly steel elements) can be recycled and used to produce new automotive parts. Cut monoliths should then be subject to the process of mechanical grinding with, for example: crushers or mills for metals in order to increase the reaction surface. Then, the mechanically comminuted catalytic monoliths are transported to the device operating on the principle of the MHD pump. The use of magneto-hydrodynamic pump for the recovery of platinum is based on the introduction of liquid metal into the channel. Around this channel there is an inductor wound on the core that produces a vortex magnetic field. This field has an axis coincident with the axis of the ring, which interacts with the electromagnetic field of the inductor to produce Lorenz force. In turn, Lorenz force causes the swirling flow of metal generating the eddy currents in the melt. Metal catalysts are panned with the following elements placed in the stream of liquid: platinum, palladium and rhodium, trapped in capillaries [1-3]. To achieve the greatest efficiency of the process, the pan should be performed for a few minutes at a constant speed, about $2-5 \mathrm{~m} / \mathrm{s}$.

The liquid metal used in the recovery of platinum is lead, undergoing a melting process above the melting point of lead (about $330^{\circ} \mathrm{C}$ ). In order to use lead in the installation it is recommended to refine it in order to remove, for example: sulfur, zinc and magnesium. The liquid and void of pollutions lead is supplied to the chamber of the device operating on the principle of MHD pump. Lead contained in leachate and discharged from the device MHD can be reused in production of liquid lead. Applying lead leachate to flush catalytic converters several times, makes the platinum group metals go to the liquid metal. For this reason, the concentration of precious metals is higher and higher for reaching the level ensuring profitability of this process. 


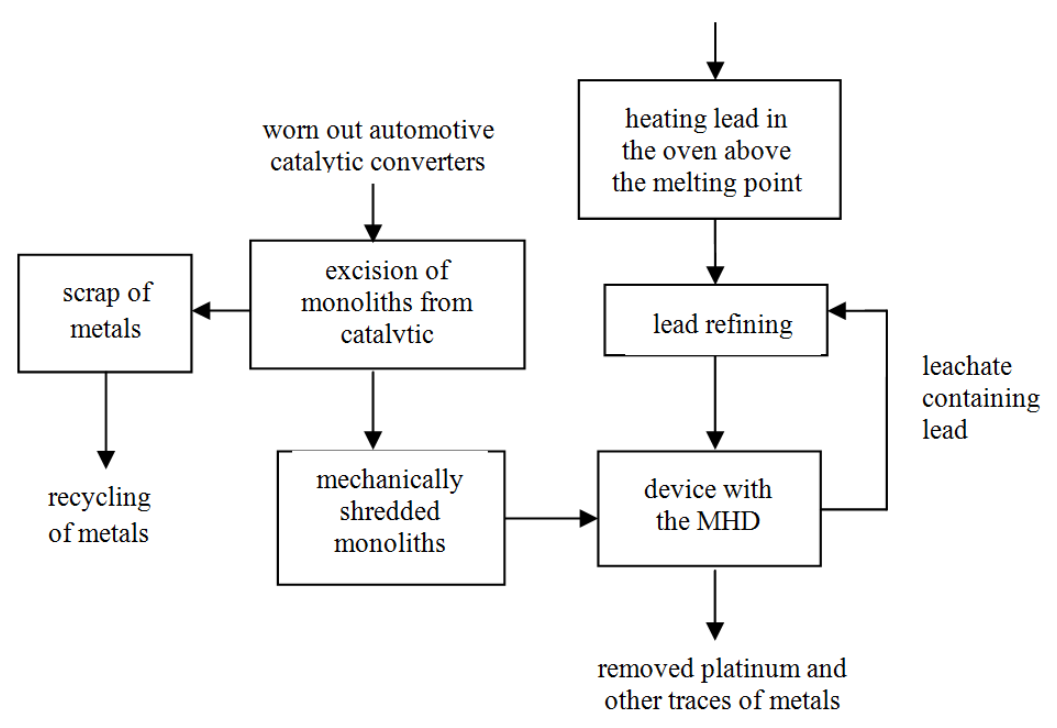

Fig. 3. The scheme of recycling worn out automotive catalytic converters

In proposed scheme, only the pump with running or rotating field can be applied. For this reason, it is necessary to consider issues concerning designing magneto-hydrodynamic pumps, especially difference in pressure and needed liquid flux. To design device with MHD pump, it is essential to solve problems, which are following $[8,13]$ :

- before the start, the channel of the pump has to be fulfilled with the liquid metal to $2 / 3$ of its volume,

- during the process, the temperature above the temperature of metal melting should be constantly kept,

- after the process, the metal should be removed from the pump channel.

A significant impact on the recovery of metals has an electromagnetic field. The analysis of electromagnetic field is carried out based on the equation [6]:

$$
\nabla x\left(\frac{1}{\mu} \nabla x A\right)+j \omega \sigma A=J_{s}
$$

where: A - magnetic vector potential,

$\mu$ - magnetic permeability,

$\omega$ - angular frequency,

$\sigma$ - conductivity,

$\mathrm{J}_{\mathrm{S}}$ - surface density of forced current.

Variable electromagnetic field generates electromagnetic force according to equations [8]: 


$$
\begin{aligned}
& f_{m}=\frac{1}{2} \operatorname{Re}(J x B) \\
& J=j \omega \sigma A \\
& B=\nabla x A
\end{aligned}
$$

where: $f_{m}$ - the value of magneto-dynamic force,

B - magnetic induction,

$\mathrm{J}$ - surface density of current.

To check the hydraulic parameters, it is necessary to solve Navier-Stokes equation [6]:

$$
\rho\left[\frac{\partial v}{\partial t}+v * \operatorname{grad} v\right]=-\operatorname{grad}(p)+\rho * g+\frac{\eta_{d}}{\rho} * \Delta v+f_{m}
$$

where: $\rho$ - density,

$\mathrm{p}$ - pressure,

g - gravitational acceleration,

$\eta_{d}$ - dynamic viscosity coefficient.

The whole analysis of electromagnetic field demands special numerical programs, for instance FLUX [2].

In terms of the high efficiency methods with application of magnetohydrodynamic pump, the proposed system would probably allow to recovery about $98 \%$ platinum, $95 \%$ rhodium and palladium. Because of small concentration of precious metals in automotive catalytic converters, the whole undertaking may be more profitable if we utilize catalytic converters on a greater scale using several items. The main disadvantage of this method is that it uses a hazardous metal (lead). Lead is harmful both to the environment and human health. However, the unfavorable influence should be limited by using closed cycle of liquid metal. Risks associated with the use of lead also require adequate ventilation in site where the entire installation would be located.

\section{Summary}

Recently, there has been a rapid development of the automotive industry. The growth of the number of cars driving on the roads generates the enormous amount of automotive waste. Scrapping cars pose a significant threat to the environment due to the content of ferrous and other substances dangerous for the environment, for example: oil, coolants, spent batteries. A large number of car elements make up a raw material, so it is vital to reprocess the waste aimed to 
produce new automotive parts. The management of scrapping vehicles is widespread in the world, especially in developed countries. In most European countries there are many businesses dealing with the scrapped cars. Germany and Italy lead in the field of automotive scrap. The regulations implemented in Poland and the phenomenon so-called "Gray zone" means that the waste management progresses lower than in other developed countries of the European Union.

Used catalytic converter is a valuable source of platinum. Currently, worn out catalytic converters are processed in application of pyrometallurgical or hydrometallurgical methods. In Poland there are no installations which might recycle used automotive catalytic converters and so, many private entrepreneurs are engaged in buying worn out automotive catalytic converters and in turn, automotive catalytic converters are exported abroad. An alternative solution could be the development of catalytic converters with the application of a magneto-hydrodynamic pump. This proposition is innovative and has never been applied. Due to high prices of precious metals, the proposed scheme could be a new method of platinum recovery. The whole undertaking is beneficial from the economical point of view and while maintaining proper precautions, does not cause the contamination of the environment.

\section{References}

[1] Bursa J.: Recykling części samochodowych, III Konf. N-T „Pojazd a środowisko", Radom 2001.

[2] Drzewiecki P.: Urządzenie do odzysku platyny ze zużytych katalizatorów samochodowych przy wykorzystaniu pompy magneto-hydrodynamicznej, Materiały Śląskiego Środowiskowego Studium Doktoranckiego, Gliwice 2013.

[3] Fikus F., Wieczorek T.: Urządzenia magnetohydrodynamiczne w odlewniach i hutach, Śląsk, Katowice 1997.

[4] Fornalczyk A., Saternus M.: Utylizacja katalizatorów samochodowych na drodze hydrometalurgicznej, XV Konf. N-T „Produkcja i Zarządzanie w Hutnictwie”, Częstochowa 2007.

[5] Frącz W., Stachowicz F.: Materials recovery from used lead-acid batteries, 7-th Int. Multidisciplinary Conf., Baia Mare 2009, pp. 157-162.

[6] Golak S., Przyłucki R.: The optimization of an inductor position for minimization of a liquid metal free surface, Electrical Review, 11 (2008), pp.163-164.

[7] Hagelüken C.: Recykling von Autoabgaskatalysatoren - Stand und Perspektive für Europa, Metall, 49 (1995), p. 486.

[8] Leboucher L., Boissonneau P.: Channel shape optimization of electromagnetic pumps, IEE Transactions on Magnetics. 31/3 (1995), pp. 2142-2145.

[9] Lejda K., Stachowicz F.: Odzysk metali w procesach recyklingu oraz uwarunkowania w rozwoju konstrukcji samochodów, ZN OBR SM BOSMAL, 32 (2006), pp. 33-44. 
[10] Liu S.X., Winslow G.R., Yester S., Gromek G.P, Crouch A., Sendijarevic V.: Shredding late model Chrysler vehicles, ASR sample collection and characterization of ASR, SAE Trans., 980480 (1998) 378-389.

[11] Małuszyńska I., Bielecki B.: Recykling odpadów wycofanych z eksploatacji jako metoda ograniczająca ilość odpadów niebezpiecznych w środowisku, Ochrona Środowiska i Zasobów Naturalnych, 48 (2011), pp. 12-15.

[12] Osiński J., Żach P.: Wybrane zagadnienia recyklingu samochodów, WKił, Warszawa 2006.

[13] Pragłowska-Gorczyńska Z.: Static characteristics of electrodynamic feeder for liquid zinc, Acta Technica Napocensis Series: Applied Mathematics, Mechanics and Engineering, 48 (2003), pp. 313-324.

[14] Stachowicz F.: Recovery of metals from used electric batteries, Progressive Technologies and Materials, OW PRz, Rzeszów 2007, pp. 123-135.

[15] Stachowicz F.: Reuse, recovery and recycling of metals from end of life vehicles, Progressive Technologies and Materials, OW PRz, Rzeszów 2005, pp. 93-103.

\title{
RECYKLING KATALIZATORÓW SAMOCHODOWYCH Z ZASTOSOWANIEM POMPY MAGNETO-HYDRODYNAMICZNEJ
}

\begin{abstract}
Streszczenie
Katalizator samochodowy jest częścią układu wydechowego w pojazdach, montowany w celu zmniejszenia ilości szkodliwych substancji zawartych w spalinach. Konieczność stosowania katalizatorów samochodowych nakazują rygorystyczne normy w zakresie emisji spalin, zwane EURO normami. Zużyte katalizatory są cennym źródłem platyny. Obecnie zużyte katalizatory są przetwarzane przy zastosowaniu metod metalurgii ogniowej lub hydrometalurgii. W Polsce nie ma żadnej instalacji zaprojektowanej w celu recyklingu zużytych katalizatorów samochodowych zużyte katalizatory są odkupowane przez indywidualnych przedsiębiorców i eksportowane za granicę. W artykule przedstawiono charakterystykę katalizatorów samochodowych oraz przegląd standardów emisji spalin, jak również rozwiązanie recyklingu katalizatorów, które pozwala odzyskać metale szlachetne zawarte w katalizatorach.
\end{abstract}

Słowa kluczowe: katalizatory samochodowe, normy EURO, pompa magneto-hydrodynamiczna, recykling

DOI: $10.7862 / \mathrm{rm} .2016 .7$

Otrzymano/received: $24.02 .2016 r$.

Zaakceptowano/accepted: 15.03.2016 r. 